\title{
The Role of Notary in Binding The Security with Liability Rights
}

\section{Muhammad Zaky Mushaffa*)}

*) Public Notary in Pekalongan, Central Java, Email: zakymust.s2@gmail.com

\begin{abstract}
This research aims to determine the role of the notary in binding collateral with immovable property rights, obstacles and solutions in the implementation of binding mortgage rights and legal consequences if it is done not in front of a notary. This study uses an approach Juridical Empirical, namely legal research by approaching the existing facts by conducting research and then being reviewed and reviewed based on the relevant laws and regulations as a reference for solving problems. The result are (1) The role of a notary in binding immovable property collateral is very important, referring to article 15 paragraph (1) of the UUHT which stipulates that the Power of Attorney to Impose Mortgage Rights (SKMHT) must be made with a notary deed or deed PPAT (2) The obstacles that occur in the collateral binding process with mortgage rights can be mapped in two stages, namely the pre-binding stage, generally related to the filing of binding requirements such as the identity of the parties, the object of guarantee, and the parties' authority to act and the stage after the binding, at generally related to the attitude of the debtor and the binding process at the local National Land Agency. (3) Legal consequences of binding collateral if not carried out before a notary include the signed agreement loses its authenticity as stipulated in Article 16 paragraph (8) UUJN.
\end{abstract}

Keywords: Agreement; Notary; Mortgage.

\section{INTRODUCTION}

Cooperative has functions to build and develop the economic potential and capacity of members in particular and society in general to improve their economic and social welfare; participate actively in efforts to enhance the quality of human life and society; strengthening the people's economy as the basis for the strength and resilience of the national economy with cooperatives as the mainstay of teachers. ${ }^{1}$ Acting as a driving force and an effective means of mobilizing funds as well as a careful channeler of these funds in the form of financing to finance productive business activities which occupy the dominant amount of all productive assets of the cooperative with the aim of earning income.

In protecting and securing the funds of cooperative members that are managed and entrusted to the cooperative, sharia savings and loan and financing business activities

\footnotetext{
${ }^{1}$ Article 4 of Act No. 25 of 1992 concerning Cooperatives
} 
are carried out based on sharia principles with good governance, applying the principles of prudence and risk management, and complying with regulations related to saving business management borrowing and sharia financing. ${ }^{2}$

Analysis and research is needed on the character, capabilities, capital, collateral, and business prospects of prospective members of the financing, known as the $5 \mathrm{C}$ principle which includes Character; Capital; Capacity; Condition of economy and Collateral. This concept can provide information regarding the good faith (willingness to pay) and the ability to pay (ability to pay) members of the financing in repaying the financing along with the margin and other expenses. ${ }^{3}$

The provision of financing by the cooperative is accompanied by the delivery of collateral by the prospective financing member and binding collateral at the time of the financing contract. The right to land is a guarantee that cooperatives prefer, because land rights are generally easy to sell, continue to increase in price, have proof of rights, are difficult to embezzle and can be burdened with mortgage rights that give creditors special rights. ${ }^{4}$ The role of a notary is indispensable in binding collateral and granting mortgage rights. Both cooperatives and financing members need legal certainty as authentic evidence of their actions, agreements they make because of their own will, so they need the assistance of a notary as a public official who has the authority to make authentic deeds because their actions, agreements or provisions are required by the applicable laws and regulations ${ }^{5}$.

Description above describes the distribution of funds from the cooperative to financing members (debtors) based on an assessment of achievement fulfillment capabilities ${ }^{6}$ according to the period agreed by the debtor. Also supported by binding collateral with Mortgage Rights. That matter meaning that the debtor must pay attention to the contents of the financing agreement he has signed, starting from the definition, the obligations arising from the agreement, and the consequences of default resulting in loss of title to the collateral tied to the agreement.

\section{METHODS}

This study uses an approach Juridical Empirical, namely legal research by approaching the existing facts by conducting research and then being reviewed and reviewed based on the relevant laws and regulations as a reference for solving problems.

\footnotetext{
${ }^{2}$ Article 22 paragraph (1) Regulation of the Minister of Cooperatives and Small and Medium Enterprises of the Republic of Indonesia No. 16/Per/M.KUKM/IX/2015

3Usman, Rachmadi. (2001). Aspek-Aspek Hukum Perbankan di Indonesia. Jakarta: Gramedia Pustaka, p. 246.

${ }^{4}$ Effendi Warsin. (1991). Praktek Penggunaan Tanah sebagai Agunan Kredit. Jakarta: Rajawali Pers, p.ix

${ }^{5}$ Yensih, \& Sukarmi, Hanim, Lathifah. (2019). The Law Strength Of Under Hand Deed That Has Passed By Notary as an Authentic Deed in the Proof of Civil Case in District Court of Cirebon. JURNAL AKTA: Vol. 6, No. 4, 661-668. Retrieved from http://jurnal.unissula.ac.id/index.php/akta/article/view/7596

${ }^{6}$ Article 1234 of the Civil Code
} 


\section{RESULTS AND DISCUSSION}

\subsection{Role of Notary in Binding Collateral with Mortgage Rights}

As an institution who act as an intermediary between parties with surplus funds (surplus of funds) and parties lacking funds (lack of funds) KSPPS (Cooperative for Savings and Loans and Sharia Financing) owns role as an actual financial institution, namely as a public financial intermediary (financial intermediary) ${ }^{7}$, carry out its activities in the financial sector.

Lending and sharia financing to members, prospective members and other cooperatives and/or members in the form of loans based on a Qard contract and financing with Murabahah, Salam, Istishna, Mudharabah, Musyarakah, Ijarah, Ijarah Muntahiya Bittamlik, Wakalah, Kafalah and Hiwalah, or akad others that do not conflict with sharia. ${ }^{8}$ Prospective members and members are the embodiment of the owner and user of cooperative services. ${ }^{9}$

The financing process is carried out through submitting a financing application, financing analysis of good faith and the ability and ability of the debtor to pay off his financing as agreed. When this stage has been passed, identification and verification of the goods that will be used as financing collateral is carried out ${ }^{10}$ with a view to:

a. Legal certainty of collateral position, whether the collateral legally belongs to the prospective financing member.

b. The guarantee value relaxation is related to the value of the financing to be distributed, whether it meets the financing value or not.

After the entire process has been completed, a Financing contract is made followed by binding collateral with Mortgage Rights. This is where the notary plays an important role in the financing contract and collateral binding, because the financing contract is an authentic deed because of the Notary's authority, namely to make an Authentic deed. ${ }^{11}$ Referring to Article 15 paragraph (1) UUHT determines that the Power of Attorney to Impose Mortgage Rights (SKMHT) must be made with a Notary deed or a PPAT deed.

The notary makes the deed because there is a request from the parties facing him, without any request from the parties, the Notary will not make any deed, and the Notary makes the deed based on evidence or statement or statement of the parties that are stated or explained or shown to or before a Notary Public, and subsequently the Notary framing outwardly, formally and materially in the form of a Notary deed, by

\footnotetext{
7Jumhana, Muhammad. (2012). Hukum Perbankan di Indonesia. Bandung: PT. Citra Aditya Bakti, Print.VI, p. 97

${ }^{8}$ Article 21 (1) PerMen KUKM RI No. 16/Per/M.KUKM/IX/2015 concerning Implementation of Sharia Savings and Loan Business Activities by Cooperatives

${ }^{9}$ Chapter V Article 17 of Act No. 25 of 1992 concerning Cooperatives

${ }^{10}$ Interview with Lukman, SH, Legal Section of KSPPS BMT BAHTERA on 21 February 2017.

${ }^{11}$ Article 15 Law of the Republic of Indonesia No. 2 of 2014 concerning Amendments to Act No. 30 of 2004 concerning the Position of Notary Public
} 
still adhering to the legal rules and procedures or procedures for making deeds and legal rules relating to the legal action concerned as stated in the deed. ${ }^{12}$

\subsection{Obstacles in the Implementation of Collateral Bonding with Mortgage Rights and their Solutions}

The existence of a material guarantee needs to be bound, that is, with a legal bond in order to have clear legal certainty for both creditors and debtors with the aim of facilitating the execution process. The process of assigning mortgage rights is carried out in two stages:

a. The stage of granting mortgage rights, by making the Deed of Granting Mortgage Rights by the Official of Making Land Deeds ${ }^{13}$, hereinafter referred to as PPAT, which is preceded by a debt or credit agreement or guaranteed.

b. The registration stage by the Land office, which is the time when the security rights are charged. In the position as mentioned above, the deeds made by PPAT are in the form of authentic deeds. ${ }^{14}$

Obstacles in implementing collateral binding with mortgage rights and solutions, the authors present in the table below: ${ }^{15}$

No.

Resistance

Solution

1 The order letter from the bank or cooperative is received by the notary two hours before the credit agreement, so that the notary does not have enough time to check the completeness of administration or confirmation to BPN

Provide counseling to the Bank/Cooperative regarding order procedures carried out to the Notary.

2 For banks or conventional cooperatives for multipurpose credit, not accompanied by an SP3, even though SP3 is accompanied by an SP3 that has
indispensable in making a been signed by the debtor, this is Understand to the Bank/Cooperative that the files submitted to the Notary must be

\footnotetext{
${ }^{12}$ Adjie, Habib. (2005). Hukum Notaris dan Penafsirannya dalam Undang-undang No. 30 Tahun 2004 tentang Jabatan Notaris. Bandung: Rafika Adisama. p. 24

${ }^{13}$ Arrohim, Mohammad B., \& Wahyuningsih, Sri Endah. (2020). Analysis of Judicial Application of Criminal Penalty Against Notary / Land Deed Officials Conducting Making Crime of the Fake Authentic Deed in State Court of Semarang. JURNAL AKTA: Vol.7, No. 2, 183-188. Retrieved from http://jurnal.unissula.ac.id/index.php/akta/article/view/7891

${ }^{14}$ Harun, Badriah. (2010). Troubled Credit Dispute Resolution: Legal Action and Alternative Settlement of All Types of Non-Performing Loans. Yogyakarta: Pustaka Yustisia, p. 73.

${ }^{15}$ Interview with Notary and PPAT Lies Andriyani SH, S.PN. on 13 February 2017 and Interviews with Sudjoko and Sugeng S, BPN/ATR of Pekalongan on 6 March 2017
} 
contract in a notary.

to facilitate the making of PK.

3 Often there are differences in the The Notary comes to the names listed on the SK Bank/Cooperative to ask for Bank/Cooperative which is signatures from the Official authorized to represent the appointed by the Bank in Bank/Cooperative, accordance with SK submitted to the Notary

4 Sometimes the signing of the After the PK occurs, at the end of agreement of the parties is carried out outside the city outside the position of notary public the credit deed a clause is added that the implementation of the PK signature is carried out outside the city

5 There is still bargaining for SP3 The bank/cooperative is welcome between the debtor and the bank/cooperative, especially in terms of interest/profit sharing, even though the debtor has signed and approved the SP3 to provide an explanation to the debtor about the signed SP3, where the SP3 includes details of the debtor's payment obligations to the bank/cooperative.

6 There is a difference in the name This is done by making a of the debtor that is listed on the KTP, KK and the certificate. statement from the debtor stating that the difference in the names listed on the KTP, KK or certificate is the same name or the debtor completes by adding a statement from the village regarding the difference in the names listed on the KTP, KK or certificate.

7 There is a difference in the hours stated in the contract and the actual time when the contract occurs.
The hours listed on the deed are emptied first, then they are reprinted according to the actual events.

8 Change of power of attorney from the bank/cooperative if there is a change in the management structure in the bank/cooperative

The Notary Party requests the latest SK from the Bank/Cooperative for the Party appointed to represent the 
eISSN : 2581-2114, pISSN: 2406-9426

has not been submitted to a Bank/Cooperative

notary when the contract occurs

9 When a take-over credit occurs, sometimes the bank/cooperative keeps the data on the number of times the take-over has occurred, even though if there is a takeover and the PK must be synchronized.

The Notary Party confirms to the BPN regarding the position of the collateral attached to the Mortgage
10 The debtor sometimes denies that he has signed the PK before the notary.
The original archive or file must be checked and shown to the Notary and under the photo copy of the debtor's KTP, signed by the person concerned.

11 The length of time for checking the certificate and data input at The notary party must play an BPN active role to confirm to BPN

12 Differences in the recipients of Bank/Cooperative power at the time of making the SKMHT and the APHT application process.

A certificate explaining the change in the power of attorney for the Bank/Cooperative
13 The difference between the holder of the Mortgage and the Certificate of Settlement for the cancellation of the Mortgage (to be done by roya).

\subsection{Legal Consequences of Collateral Binding If Not Performed Before a Notary Public}

In the provision of financing, an agreement is made followed by a guarantee binding, this is intended to protect the interests of the cooperative, therefore, the provisions and legal consequences associated with the binding of the financing guarantee object are made, which will be received if it is completely tied or otherwise. The legal consequences if the binding is not carried out in front of a notary are as follows:

a. The agreement made is an underhand deed or has lost its authenticity as stated in Article 16 paragraph (8) of the UUJN, resulting in the deed being unable to be registered. 
b. As the recipient of the Mortgage, if the collateral is imposed under the hand, the creditor does not get a priority position (droit de preference)

c. If there is default, the guarantee cannot be executed immediately.

d. Proof of the deed that is made does not apply to third parties.

e. If there is a dispute/dispute between the two parties, the only settlement that can be reached is through amicable settlement, it cannot be continued to legal channels.

f. Affecting the motivation of members of the financing to fulfill their performance well, this usually greatly affects the smoothness of the members' installments in fulfilling their obligations. ${ }^{16}$

\section{CLOSING}

The legal consequence of binding collateral if it is not performed before a notary public (1) pthe agreement made loses its authenticity as stated in Article 16 paragraph (8) UUJN, (2)creditor does not have priority position (droit de preference), (3) bIf there is a default, the guarantee cannot be executed immediately, (4) proof of the deed that is made does not apply to a third party, so that the settlement is taken only through amicable settlement, (5) affects the motivation of the members of the financing to fulfill their performance properly.

\section{References}

Journals:

Arrohim, Mohammad B., \& Wahyuningsih, Sri Endah. (2020). Analysis of Judicial Application of Criminal Penalty Against Notary / Land Deed Officials Conducting Making Crime of the Fake Authentic Deed in State Court of Semarang. JURNAL AKTA: Vol.7, No. 2, 183-188. Retrieved from http://jurnal.unissula.ac.id/index.php/akta/article/view/7891

Yensih, \& Sukarmi, Hanim, Lathifah. (2019). The Law Strength Of Under Hand Deed That Has Passed By Notary as an Authentic Deed in the Proof of Civil Case in District Court of Cirebon. JURNAL AKTA: Vol. 6, No. 4, 661-668. Retrieved from http://jurnal.unissula.ac.id/index.php/akta/article/view/7596

Books:

Adjie, Habib. (2005). Hukum Notaris dan Penafsirannya dalam Undang-undang No. 30 Tahun 2004 tentang Jabatan Notaris. Bandung: Rafika Adisama

Effendi Warsin. (1991). Praktek Penggunaan Tanah sebagai Agunan Kredit. Jakarta: Rajawali Pers

Harun, Badriah. (2010). Troubled Credit Dispute Resolution: Legal Action and Alternative Settlement of All Types of Non-Performing Loans. Yogyakarta: Pustaka Yustisia

Jumhana, Muhammad. (2012). Hukum Perbankan di Indonesia. Bandung: PT. Citra Aditya Bakti, Print.VI

Usman, Rachmadi. (2001). Aspek-Aspek Hukum Perbankan di Indonesia. Jakarta: Gramedia Pustaka

${ }^{16}$ Interview with Hariadi Prihatmanto, SE, KSPPS BMT An Najah Financing Manager on 11 February 2017 
Regulations:

Article 1234 of the Civil Code

Article 15 Law of the Republic of Indonesia No. 2 of 2014 concerning Amendments to Act No. 30 of 2004 concerning the Position of Notary Public

Article 21 (1) PerMen KUKM RI No. 16/Per/M.KUKM/IX/2015 concerning Implementation of Sharia Savings and Loan Business Activities by Cooperatives

Article 22 paragraph (1) Regulation of the Minister of Cooperatives and Small and Medium Enterprises of the Republic of Indonesia No. 16/Per/M.KUKM/IX/2015

Article 4 of Act No. 25 of 1992 concerning Cooperatives

Chapter V Article 17 of Act No. 25 of 1992 concerning Cooperatives

Interviews:

Interview with Hariadi Prihatmanto, SE, KSPPS BMT An Najah Financing Manager on 11 February 2017

Interview with Lukman, SH, Legal Section of KSPPS BMT BAHTERA on 21 February 2017.

Interview with Notary and PPAT Lies Andriyani SH, S.PN. on 13 February 2017 and Interviews with Sudjoko and Sugeng S, BPN/ATR of Pekalongan on 6 March 2017 